\title{
Response of Banks to Fiscal Policy Stimuli in Nigeria
}

\author{
Ogbonna, Udochukwu Godfrey Ph.D ${ }^{1} \quad$ Ejem, Chukwu Agwu, Ph.D ${ }^{2}$ \\ 1.Department of Management Science, Rhema University, Aba, Nigeria \\ 2.Department of Banking and Finance, Abia State University, Uturu, Nigeria
}

\begin{abstract}
This study went into much neglected area of research; relationship between fiscal policy instruments and performance of banks in Nigeria. Various finametric tools were used to analyze data collected from Nigerian Deposit Insurance Cooperation and Central Bank of Nigeria for period of 1989 to 2018 inclusive. Resounding empirical findings were made as follows; Bank performance is autoregressive. That suggests that performance of banks in the past cannot be predicting future bank performance. It was conspicuously observed that Capital Expenditure, Non-Oil Revenue and Domestic Debt have positive and significant relationship with bank performance, while Recurrent Expenditure Domestic Debt afterwards negatively and significantly impact bank performance. It was also found that fiscal policy variables (Capital Expenditure, Recurrent Expenditure, Non-Oil Revenue and Domestic Debt) significantly impact bank performance both in the short run and long run. Since fiscal policy variables are found to exert significant impact banks' performance in Nigeria, the researchers suggests to Federal government of Nigeria as a matter of urgency reconsiders the operation of Treasury Single Account. It is the view of the researchers that the Treasury Single Account be operated through deposit money banks by domesticating various Ministries, Departments and Agencies (MDAs) account with the deposit money banks.
\end{abstract}

Keywords: Bank Performance, Fiscal Policy, ARDL, Nigeria.

DOI: $10.7176 / \mathrm{RJFA} / 11-8-12$

Publication date: April $30^{\text {th }} 2020$

\section{Introduction}

During the classical era, government fiscal policy was understood to mean all the activities of government aimed at procurement or raising and spending or distribution of money to pay for the cost of operating government, with no consideration for employment and output as it is today. Since the great depression of 1930s, the term fiscal policy has been applied to refer to those activities of general finance, which have to do with the reduction of economic instability and the stimulation of employment and long run economic growth. Fiscal policy may also be viewed as an articulated framework detailing how fiscal policy instruments can be varied by government to influence the long run growth of the economy, especially the growth rates of employment and national income (Onoh, 2007).

Onoh (2007) observe that if the instruments of expenditure and receipt are properly synchronized with other macroeconomic policy instruments from the monetary, institutional and the direct economic interventions the arena economy becomes stabilized and the macroeconomic objectives of higher levels of employment, national income and balance of payment equilibrium become realized to a large extent. If fiscal policy instruments are projected without reference to monetary, institution and intervention policies the economy could be in disarray and the desired macroeconomic objectives become illusive and difficult to attain. Fiscal policy should therefore be synchronized with other economic policies and should not be at variance with them.

Apart from the monetary policy, the instruments of fiscal policy should be able to effective and efficiently enhance the performance of banks. This is because imprudent public spending and weak sectoral linkages and other socioeconomic maladies constitute the bane of rapid economic growth and development (Amadi,and Essi, 2006).

The fact that resolving banking sector non performance often involves substantial government expenditure means that the fiscal balance become a constraint on the type of corrective action that can be taken. Banking sector problem are often known but ignored, and regulatory and supervisory authorities are most at times prevented from intervening in the banks because this would bring the problems out in the open and trigger government expenditure. The justifications for inaction are that there is no room in the budget or that the fiscal situation is too weak to allow for any consideration of banking problems.

Despite the aforementioned, Lindgren, Garcia and Saal (1996), suggested that, it is essential for efficient resource allocation so that banking system problems will not be swept under the rug in fiscal policy formulation. The government's full costs, including estimated contingency costs, need to be taken into consideration in a transparent way. This called for this study; Response of Banks to Fiscal Policy Stimuli. This is to know how banks react to fiscal policy measures in Nigeria.

The remaining sections of this study are arranged as follows; section two jointly reviews related literature; section three takes care of the methodology; section four analyses the data and interpret results, whereas section five is about concluding remarks and recommendations, finally section six handles suggestion for further studies 
and limitation of the study.

\section{Literature Review}

Conceptually, fiscal Policy is the budgetary policy of the government relating to revenue (taxes), public expenditure, public borrowing and deficit financing (Sanni, 2012). Yusuf (2017), fiscal policy refers to government's management of the economy through the changes of its income and spending abilities. Fiscal is the use of government revenue collection and spending as a mechanism to influence an economy (Gregory 2014; Taylor, 2017; Omodoro and Dandago, 2018). Jhingan (2002) referred fiscal policy as a powerful instrument of stabilization. Njoku (2009) defined fiscal policy as changes in taxes, expenditure and borrowing, which aims at short run stability. Njoku (2009) added that though the ultimate aim of fiscal policy is the long run stabilization of the economy, yet it can only be achieved by moderating short run economic fluctuations.

The two main instruments of fiscal policy are the expenditure and receipts. If properly orchestrated, the instrument of expenditure and receipts can become veritable tools and main drivers to correct the economy from careering into those paths which will not lead to higher levels of employment and output especially the banking sector which is engine the economy. Fiscal policy aligning government revenue and expenditure is crucial importance in promoting price stability and sustainable growth in output, income and employment which are important parameters of economic growth (Ahmed, 2010). Yusuf (2017), it is one of the macroeconomic policy instruments that can be used to prevent or reduce short run fluctuations in output, income and employment in order to move an economy to its potential level.

Rose and Hudgins (2010) described bank performance it in this context as how adequate a financial firm meets the needs of its stockholders (owners), employees, depositors and other creditors and borrowing customers. At the same time, financial firm must find a way to keep government regulators satisfied that their operating policies, loans and investment are sound protecting the public interest.

Theoretically, it is argued that total government expenditure adjusts more rapidly than revenue to price level variation in such a way that bank-financed budgetary deficit set in (Aghevli and Khan, 1978). For that, Wagner's law of Increasing State Activity: Wagner (1911) was a German political economist who based his law on increasing state activities and historical facts, primarily in Germany. He studied the German economy overtime and observed a correlation growth between national output and the public expenditure in the economy. He expressed the view that there was an inherent tendency for the activities of different layers of government (such as central and state governments) to increase both intensively and extensively. That is, there is a functional relationship between the growth of an economy and the growth of government activities, so that the government sector grows faster than the economy (Ezirim, 2005). In the original version of Wagner's theory, it is not clear whether he was referring to an increase in absolute level of public expenditure, the ratio of government expenditure to Gross National Product or proportion of public sector in the total economy but Musgrave (1970) interpreted that Wagner was thinking of the proportion of public sector in the total economy. Wagner expressed the view that public expenditure increase at a faster rate than the national output. That is, the share of public sector in the economy will increase as the economy growth proceeds. Wagner argued that a functional cause and effect relationship exist between the growth of an industrializing economy and the relative growth of its public sector. This long-term hypothesis has it that social progress was the basic cause of the relative growth of the government in industrializing economies. The chain reaction circumstances are that social progress leads to a growth of government functions, which in turn, leads to the absolute and relative growth of economic activity (Bhatia, 2002). Anticipated Income Theory: as recorded by Ekpung, Udude, and Uwalaka, (2015). this theory states that banks should involves themselves in a broad range of lending which may include long-term loans to business, consumer installment loans and amortized real estate mortgage loans considering the fact that the likelihood of loan repayment which generates a cash flow that supplement bank liquidity depends on the anticipated income of the borrower and not the use made of the funds per se. This implies that a high excess reserve increases profitability of banks by increasing the availability of loanable investment funds. Debt Overhang Theory Patillo (2002) used core of debt overhang theory to explain that high debt acts as an anticipated foreign tax by reducing the incentives to save and invest thereby promoting capital flight. Similarly, large debt stock somehow hinders growth through the channel of reduced investment. It is true that debt accumulation stimulates growth initially; however, past debt accumulation impairs growth by way of liquidity constraint. Importantly, debt services and repayments reduce export earnings and thus exert negative effects on growth. An inappropriate macroeconomic policy environment affects growth via poorly designed, allocation and execution of projects thereby lowering the productivity of capital.

Empirically, examining the relationship between fiscal policy and banks performance, Isek, Odumusor and Idor (2020) look at the effect of fiscal policy on the performance of banks in the Nigerian economy. The study which spanned from 1990 to 2015 made use Ordinary least square to estimate the specified model. Isek et'al (2020) result revealed that jointly fiscal policy significantly affects the bank's profitability. That separately, tax revenue government total revenue had positive and significant influence on bank's performance in Nigerian economy. 


\section{Method of Study}

\subsection{Sample Data Collection}

Taking insight from Njoku (2009) who defined fiscal policy as changes in taxes, expenditure and borrowing, this aims at achieving short run stability. The following variables emanated therein; Capital Expenditure (CEX) and Recurrent Expenditure (REX) for expenditure, Non-Oil Revenue (NOR) standing for all forms of Tax, Domestic Debt (DEBT) standing for borrowing, while Return on Assets (ROA) is proxy of bank performance. The data used are made up 30 observations from 1990 to 2018 standing for the variables were collected from Nigerian Deposit Insurance Cooperation (NDIC) and Central Bank of Nigeria (CBN).

\subsection{Techniques}

To determine the stationarity of the variables, the Augmented Dickey Fuller (ADF) unit root test is employed. For multicollinearity checking, the correlation matrix is used in this study and other relevant global usefulness check. Because of the autoregressive nature of the variables under study, Autoregressive Distributive Lags (ARDL) will engaged estimating the models and will be used as dynamic solution to the static problem of the time series. The ARDL frame work can be used to examine both short run and long run relationships as well as causal impacts (Ogbonna and Ejem, 2019).

\subsection{Model Specification}

The empirical model is functionally specified as follows;

Return on Assets $=\mathrm{f}($ Fiscal Policy Variables $)$

Return on Assets $=\mathrm{f}($ Capital Expenditure, Recurrent Expenditure,

$$
\text { Non-Oil Revenue, Domestic Debt) }
$$

$\mathrm{ROA}=\mathrm{f}(\mathrm{CEX}, \mathrm{REX}, \mathrm{NOR}, \mathrm{DEBT})$

In explicit form;

$\mathrm{ROA}=\mathrm{b}_{0}+\mathrm{b}_{1} \mathrm{ROA}_{\mathrm{t}-1}+\mathrm{b}_{2} \mathrm{CEX}+\mathrm{b}_{3} \mathrm{CEX}_{\mathrm{t}-1}+\mathrm{b}_{4} \mathrm{REX}+\mathrm{b}_{5} \mathrm{REX}_{\mathrm{t}-1}+\mathrm{b}_{6} \mathrm{NOR}+\mathrm{b}_{7} \mathrm{NOR}_{\mathrm{t}-1}+\mathrm{b}_{8} \mathrm{DEBT}+\mathrm{b}_{9} \mathrm{DEBT}_{\mathrm{t}-1}+\mathrm{e}_{\mathrm{t}-1}$ (4)

LnROA $=b_{0}+b_{1} \operatorname{LnROA}_{t-1}+b_{2} \operatorname{LnCEX}+\mathrm{b}_{3} \operatorname{LnCEX}_{\mathrm{t}-1}+\mathrm{b}_{4} \operatorname{LnREX}+\mathrm{b}_{5} \operatorname{LnREX}_{\mathrm{t}-1}+\mathrm{b}_{6} \operatorname{LnNOR}+\mathrm{b}_{7} \operatorname{LnNOR}_{\mathrm{t}-1}+$ $\mathrm{b}_{8} \operatorname{LnDEBT}+\mathrm{b}_{9} \operatorname{LnDEBT}_{\mathrm{t}-1}+\mathrm{e}_{\mathrm{t}-1}$

(5)

Where et - $_{1}$ are stochastic elements

Operational form (Apriori Expectation);

$\boldsymbol{b}_{1}, \boldsymbol{b}_{2}, \boldsymbol{b}_{3} \boldsymbol{a n d}_{\boldsymbol{1}}>\mathbf{0}$, are coefficient of CEX, REX, NOR and DEBT. It is expected that fiscal policy variables increase banks' performance.

\section{Results and Analysis}

\section{1: Trend Analysis of Data}

Let's start from the trend analysis of data. The time series plot of the data is shown in figure I below. From the figures below reveals that all trended upward indicating non-stationarity of the variables as expected. Accept ROA that recorded a sharp trend upward from 2008 to 2010. 
Figure 1: Trend Analysis of ROA, CEX, REX, NOR and DEBT

ROA

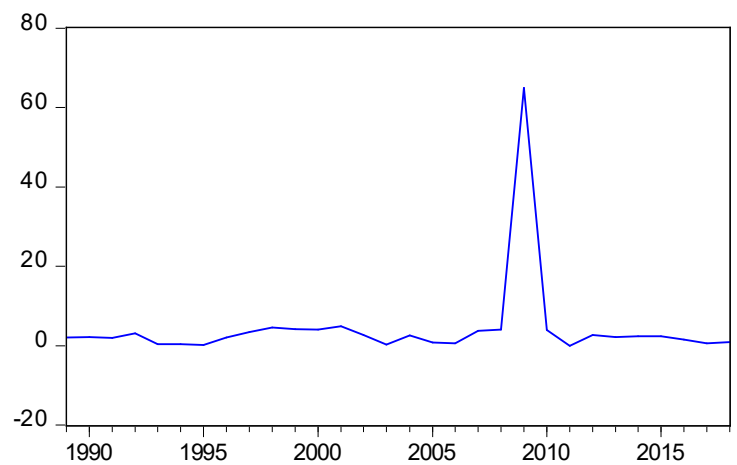

REX

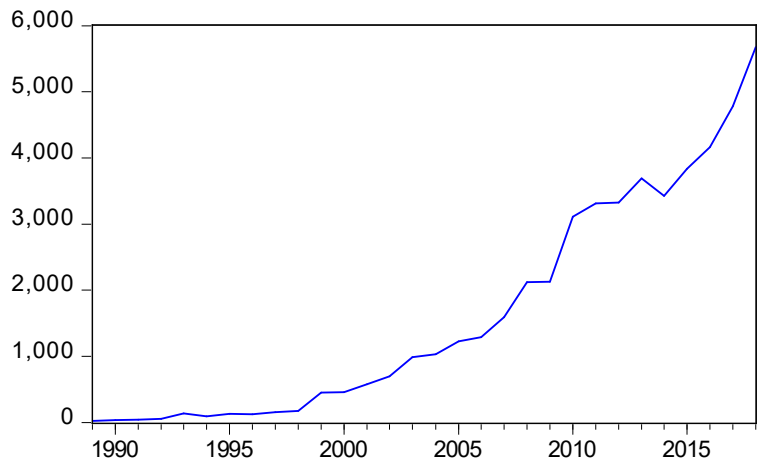

DEBT

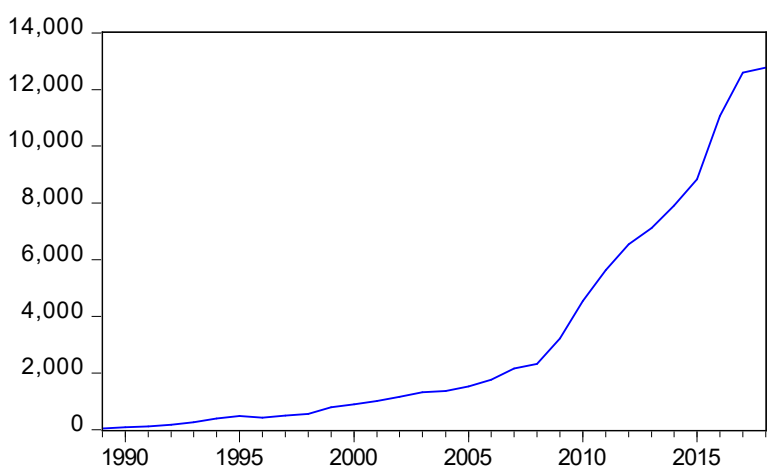

CEX

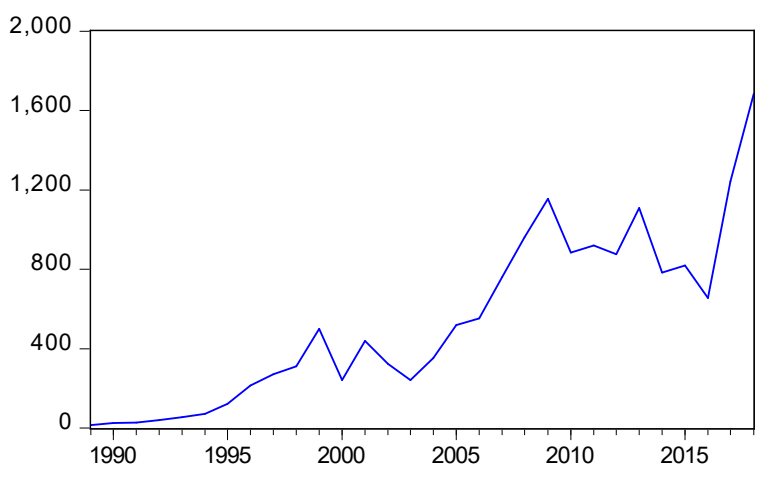

NOR

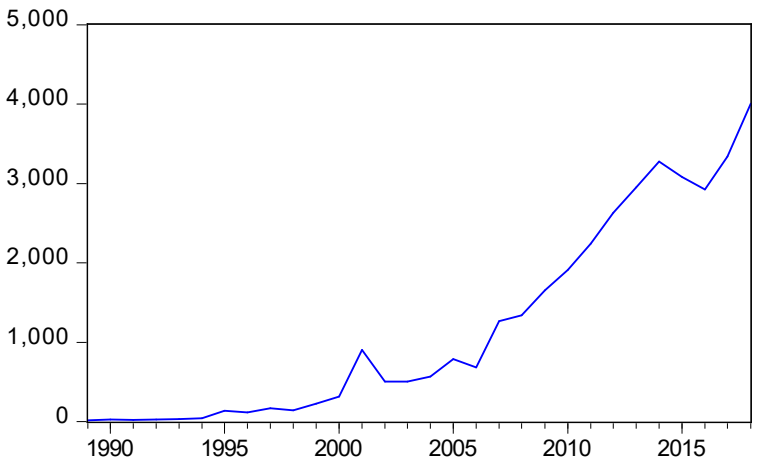

The empirical evaluation will commence with the descriptive statistical analysis;

\section{2: Description of Variables}

Table 1 below reveals summary of statistics that describe the distributional features of all the data. The variables recorded standard deviation of the following; 11.54435, 433.0433, 1688.819, 1267.325 and 3926.891 for ROA, CEX, REX, NOR and DEBT respectively. ROA and DEBT showed Kurtosis greater than 3, indicating a leptokurtic distribution, while CEX, REX and NOR are lower than 3 showing platykurtic distributions. The skewness coefficients of ROA, CEX, REX, NOR and DEBT are all positively stewed distribution. JarqueBera normality distribution test statistic p-value for ROA, and DEBT are 0.000000 and 0.015909 respectively, suggesting evidence of abnormal distribution while CEX, REX and NOR have $0.310859,0.155759$ and 0.135771 p-values which a clear evidence of normal distribution at $5 \%$. 
Table 1: Descriptive Statistics

\begin{tabular}{|l|c|c|c|c|c|}
\hline & ROA & CEX & REX & NOR & DEBT \\
\hline Mean & 4.273667 & 538.1970 & 1627.796 & 1192.854 & 3254.482 \\
\hline Median & 2.225000 & 468.3620 & 1008.500 & 621.6175 & 1350.003 \\
\hline Maximum & 64.92000 & 1682.099 & 5675.186 & 4006.000 & 12774.40 \\
\hline Minimum & -0.040000 & 15.03410 & 25.99420 & 14.73990 & 47.04960 \\
\hline Std. Dev. & 11.54435 & 433.0433 & 1688.819 & 1267.325 & 3926.891 \\
\hline Skewness & 5.070238 & 0.674997 & 0.805062 & 0.794422 & 1.275816 \\
\hline Kurtosis & 27.17311 & 2.783245 & 2.381445 & 2.181198 & 3.338424 \\
\hline & & & & & \\
\hline Jarque-Bera & 858.9608 & 2.336833 & 3.718889 & 3.993578 & 8.281695 \\
\hline Probability & 0.000000 & 0.310859 & 0.155759 & 0.135771 & 0.015909 \\
\hline Sum & 128.2100 & 16145.91 & 48833.88 & 35785.63 & 97634.47 \\
\hline Sum Sq. Dev. & 3864.890 & 5438269. & 82711146 & 46577262 & $4.47 \mathrm{E}+08$ \\
\hline Observations & 30 & 30 & 30 & 30 & 30 \\
\hline
\end{tabular}

\section{3: Global Utility Examination and Determination}

In the macroeconomic analysis, it is necessary to test the global utility or usefulness of the specified models. To achieve this, the researchers engaged correlation matrix, Normality Test, Serial Correlation Test and Heteroscedasticity Test;

\subsection{1: Multicolinearity Test}

Table 2 below reveals the correlation of the variables. The correlations between ROA, CEX, REX, NOR and DEBT range from -0.031206 to 0.0 .983966 suggesting that the variables are not linearly correlated. Therefore, the researchers have sufficient evidence to declare no presence of multicollinearity in the model.

Table2: Correlation Matrix

\begin{tabular}{|c|c|c|c|c|c|}
\hline Variables & ROA & CEX & REX & NOR & DEBT \\
\hline ROA & 1.000000 & 0.261501 & 0.030783 & 0.049585 & -0.031206 \\
\hline CEX & 0.261501 & 1.000000 & 0.902728 & 0.883588 & 0.813857 \\
\hline REX & 0.030783 & 0.902728 & 1.000000 & 0.983966 & 0.967808 \\
\hline NOR & 0.049585 & 0.883588 & 0.983966 & 1.000000 & 0.962271 \\
\hline DEBT & -0.031206 & 0.813857 & 0.967808 & 0.962271 & 1.000000 \\
\hline
\end{tabular}

\subsection{2: Normality Test}

From Table 3 below, it is observed that Jarque-Bera Statistic is 0.385603 with P- value of 0.824646 , indicating normal distribution.

\section{Table 3: Normality Distribution}

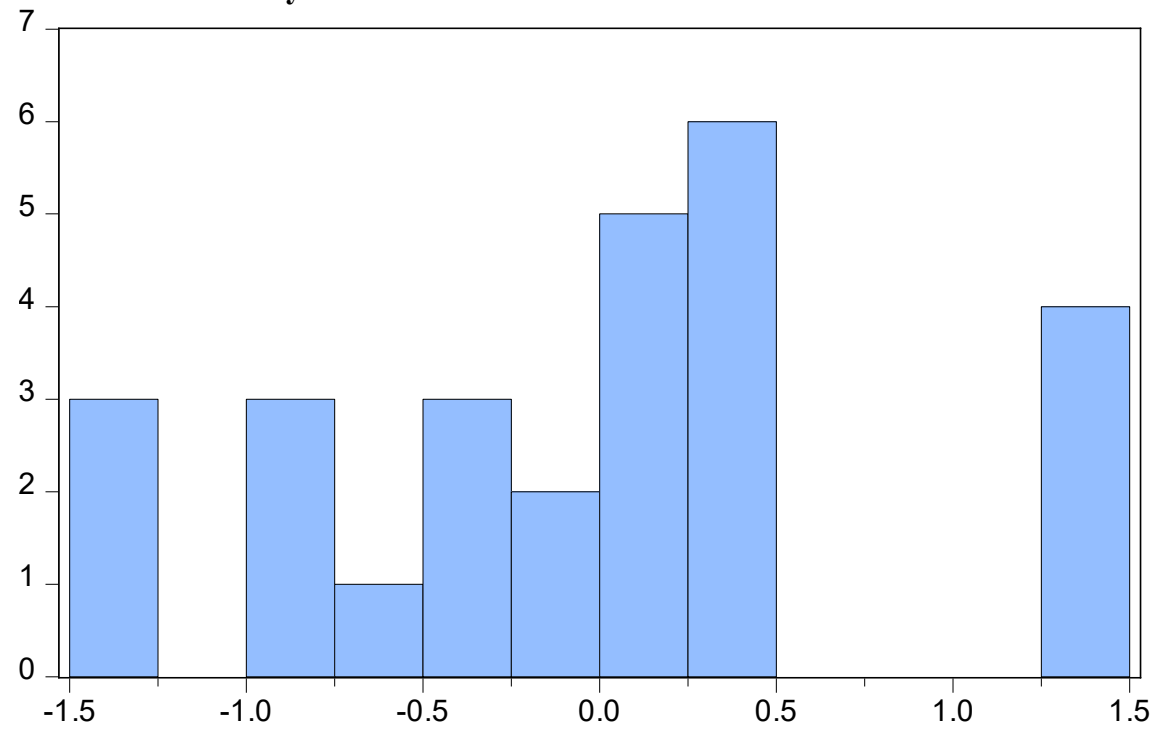

\section{Series: Residuals \\ Sample 19902018 \\ Observations 27}

$\begin{array}{lr}\text { Mean } & -1.50 \mathrm{e}-15 \\ \text { Median } & 0.092005 \\ \text { Maximum } & 1.467656 \\ \text { Minimum } & -1.498631 \\ \text { Std. Dev. } & 0.826804 \\ \text { Skewness } & 0.119118 \\ \text { Kurtosis } & 2.465209 \\ & \\ \text { Jarque-Bera } & 0.385603 \\ \text { Probability } & 0.824646\end{array}$

4.3.3: Serial Correlation Test and Heteroscedasticity Test

In the tables 4 below, Breusch-Godfrey Serial Correlation LM Tests P-value of 0.1073, which an indication of non rejection of the null hypothesis, showing evidence no serial correlation. Also Heteroscedasticity Test: ARCH with P-value of 0.4618 . This is enough evidence suggesting of homoscedasticity the model. 
Table 4: Serial Correlation Test and Heteroscedasticity Test

\begin{tabular}{|l|r|r|}
\hline \multicolumn{1}{|c|}{ Test } & F-statistic & P-value \\
\hline Breusch-Godfrey Serial Correlation LM Test: & 2.552391 & 0.1073 \\
\hline Heteroscedasticity Test: ARCH & 0.560146 & 0.4618 \\
\hline
\end{tabular}

\section{4: Stationarity/Unit Root Test}

This is s statistical proven procedure in macroeconomic time series to ascertain a suitable method for data analysis. Table 5 below shows the stationary test for both level and first difference data. The results show ROA, NOR and DEBT are stationary at level while CEX and REX are stationary or integrated at order one. The variables have different orders of integration, justifying the use ARDL model.

Table 5: ADF UNIT TEST

\begin{tabular}{|c|c|c|c|c|c|c|}
\hline \multirow[t]{2}{*}{ Variables } & \multirow{2}{*}{$\begin{array}{l}\text { Lag } \\
\text { SCI } \\
\end{array}$} & \multirow{2}{*}{\begin{tabular}{|l} 
Level \\
ADF Statistics \\
\end{tabular}} & \multirow{2}{*}{$\begin{array}{l}\mathbf{1}^{\text {st }} \text { Difference } \\
\text { ADF Statistics } \\
\end{array}$} & \multicolumn{2}{|c|}{ Critical Value } & \multirow[t]{2}{*}{ Remarks } \\
\hline & & & & $5 \%$ & $10 \%$ & \\
\hline LnROA & 6 & $-3.312727(0.0242)$ & - & -2.9976263 & -2.627420 & $@ 1(0)$ \\
\hline LnCEX & 7 & - & $\begin{array}{l}- \\
6.093663(0.0000)\end{array}$ & -2.971853 & -2.625121 & @1(1) \\
\hline LnREX & 7 & - & $\begin{array}{l}- \\
7.579425(0.0000)\end{array}$ & -2.971853 & -2.625121 & @1(1) \\
\hline LnNOR & 7 & $-4.8290388(0.0008)$ & - & -2.991878 & -2.635542 & $@ 1(0)$ \\
\hline LnDEBT & 7 & $-3.352354(0.0215)$ & - & -2.967767 & -2.622989 & $@ 1(0)$ \\
\hline
\end{tabular}

However, researchers succeeded and validated the adoption Autoregressive Distributive Lag (ARDL) to estimating the model. The researchers then proceed to model selection using Akaike Information Criterion (AIC) as shown below in Figure below.

\section{5: Model Selection}

Figure 2 below shows the ARDL model selection based on Akaike Information Criterion (AIC). Information criteria select models that minimize their values. From figure 1 below, the best model, according to AIC, is an ARDL $(1,0,0,1,1)$. This implies that a model that includes lagged value of the dependent variables as an additional regressor is the best description of researchers' data.

\section{Figure 2: Model Selection based on AIC}

\section{Akaike Information Criteria}

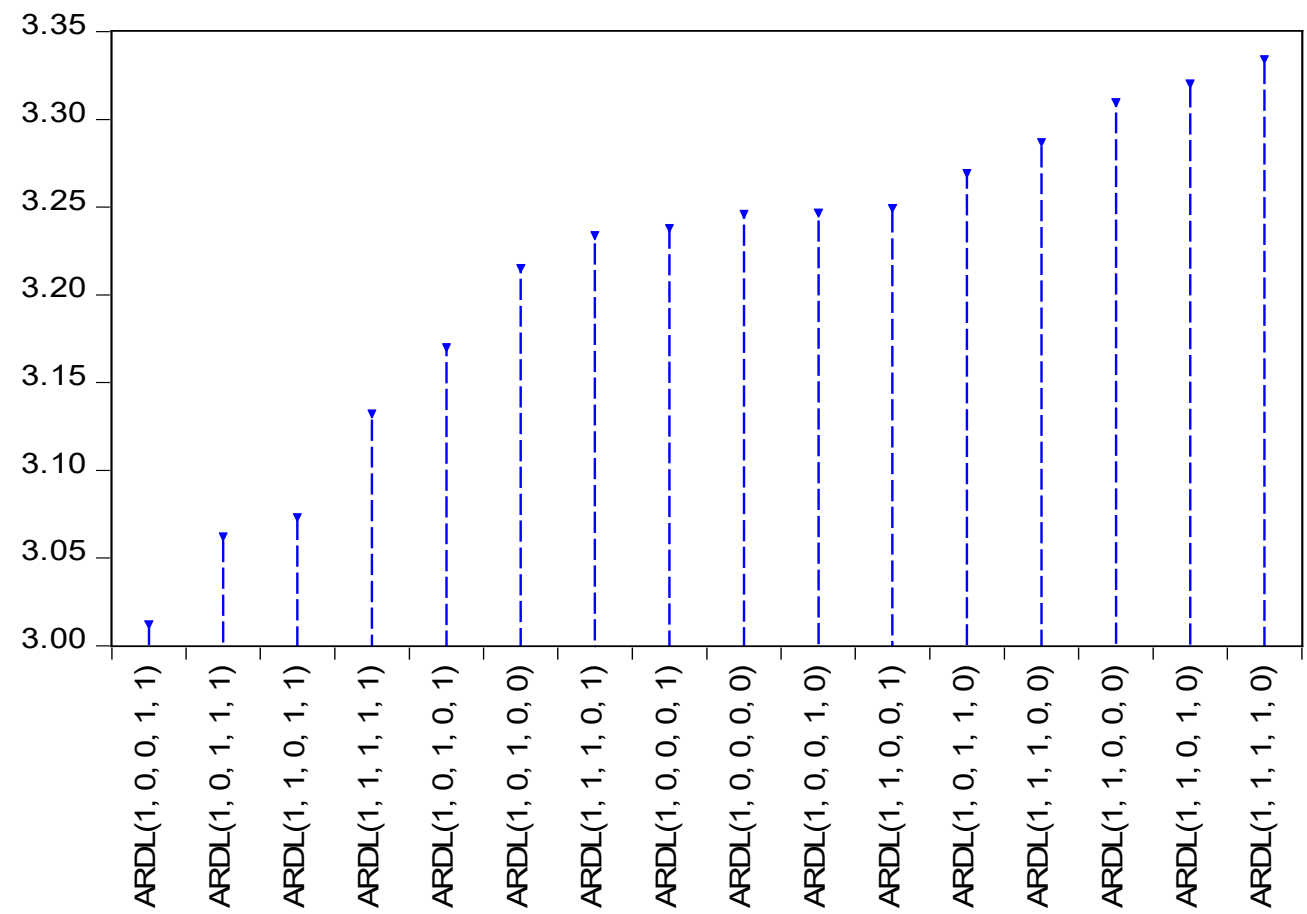

The researchers therefore move to estimating the models with ARDL as shown in table below. 


\section{6: Model Estimation and Results}

Having satisfied with all previous tests, the researchers confidently proceeded to estimating the relationship between performance of banks (ROA) and fiscal policy (CEX, REX, NOR and DEBT) in Nigeria with ARDL framework.

In the table 6 shows ROA has p-value of 0.9866 indicating it is not autoregressive. That suggests that ROA in the past cannot be predicting future occurrences. It conspicuously observed that CEX, NOR and DEBT have positive and significant relationship with ROA, while REX and DEBT at lag 1 negatively and significantly impacted ROA. The adjusted R-square is 0.415043 indicating that the estimated ARDL $(1,0,0,1,1)$ model is moderately fitted, with the explanatory variable jointly accounting for $41.5 \%$ of total variation of ROA. The probability of F-Statistic is 0.011751 , suggesting that the estimated model is highly significant. Durbin-Watson Statistics (Dw) is 2.079141 showing no need to worry about serial correlation. The researchers can boldly say that the model did a good job to describe the relationship between fiscal policy and bank performance.

Table 6: ARDL Estimation Results

Dependent Variable: LNROA

Selected Model: ARDL(1, 0, 0, 1, 1)

\begin{tabular}{|c|r|r|r|r|}
\hline Variable & Coefficient & Std. Error & t-Statistic & Prob.* \\
\hline LNROA(-1) & 0.003626 & 0.212318 & 0.017078 & 0.9866 \\
\hline LNCEX & 1.415952 & 0.537963 & 2.632064 & 0.0164 \\
\hline LNREX & -1.694149 & 0.796972 & -2.125732 & 0.0469 \\
\hline LNNOR & 0.360692 & 0.715316 & 0.504241 & 0.6199 \\
\hline LNNOR(-1) & 1.706064 & 0.661853 & 2.577707 & 0.0184 \\
\hline LNDEBT & 4.610581 & 2.195431 & 2.100080 & 0.0493 \\
\hline LNDEBT(-1) & -5.930043 & 2.262887 & -2.620566 & 0.0168 \\
\hline C & -0.525889 & 1.954698 & -0.269038 & 0.7908 \\
\hline R-squared & 0.572532 & Mean dependent var & 0.580430 \\
\hline Adjusted R-squared & 0.415043 & S.D. dependent var & 1.264592 \\
\hline S.E. of regression & 0.967191 & Akaike info criterion & 3.012354 \\
\hline Sum squared resid & 17.77372 & Schwarz criterion & 3.396305 \\
\hline Log likelihood & -32.66677 & Hannan-Quinn criter. & 3.126523 \\
\hline F-statistic & 3.635391 & Durbin-Watson stat & 2.079141 \\
\hline Prob(F-statistic) & 0.011751 & \multicolumn{4}{l}{}
\end{tabular}

\section{7: Test of long run Relationships between Fiscal Policy and Bank Performance}

Table 7 below shows ARDL Bound cointegration Test examining if there is long run relationship in the model. From the bound test, it can be seen that the F-Statistics is 5.648243 and is greater than all the critical values at 1(0) and 1(1) bounds. This reject the null hypothesis of no cointegration, meaning there is long run relationship between Capital Expediture (CEX), Recurrent Expenditure (REX), Non-Oil Revenue (NOR), Domestic Debt (DEBT) and Return on Assets (ROA) which is proxy of bank performance.

Table 7: ARDL Bound Cointegration Test

\begin{tabular}{|l|c|r|r|r|}
\hline F-Bounds Test & \multicolumn{3}{|c|}{ Null Hypothesis: No levels relationship } \\
\hline Test Statistic & Value & Signif. & I(0) & I(1) \\
\hline F-statistic & 5.648243 & $10 \%$ & 2.2 & 3.09 \\
\hline K & 4 & $5 \%$ & 2.56 & 3.49 \\
\hline & & $2.5 \%$ & 2.88 & 3.87 \\
\hline & & $1 \%$ & 3.29 & 4.37 \\
\hline
\end{tabular}

\section{8: Short run and Long run impact of Fiscal Policy Variables on Bank Performance}

The results in the table below show that fiscal policy variables have $\mathrm{p}$-values less than $10 \%$ in the cointegrating form and long run form, suggesting significance. That means fiscal policy variables (Capital Expediture (CEX), Recurrent Expenditure (REX), Non-Oil Revenue (NOR) and Domestic Debt (DEBT) significantly impact bank performance (ROA) both in the short run and long run. 
Table 8: Cointegrating and Long run Form

\begin{tabular}{|c|r|r|r|c|}
\hline Cointegrating Form & Coefficient & Std. Error & t-Statistic & Prob. \\
\hline Variable & -0.525889 & 1.954698 & -0.269038 & 0.7908 \\
\hline C & -0.996374 & 0.212318 & -4.692843 & 0.0002 \\
\hline LNROA(-1)* $^{*}$ & 1.415952 & 0.537963 & 2.632064 & 0.0164 \\
\hline LNCEX $^{*}$ & -1.694149 & 0.796972 & -2.125732 & 0.0469 \\
\hline LNREX** & 2.066756 & 0.815670 & 2.533815 & 0.0202 \\
\hline LNNOR(-1) & -1.319463 & 0.664965 & -1.984258 & 0.0619 \\
\hline LNDEBT(-1) & 0.360692 & 0.715316 & 0.504241 & 0.6199 \\
\hline D(LNNOR) & 4.610581 & 2.195431 & 2.100080 & 0.0493 \\
\hline D(LNDEBT) & & \multicolumn{3}{|}{}
\end{tabular}

\section{Long run Coefficient}

\begin{tabular}{|c|r|r|r|r|}
\hline Variable & Coefficient & Std. Error & t-Statistic & Prob \\
\hline LNCEX & 1.421105 & 0.577271 & 2.461763 & 0.0236 \\
\hline LNREX & -1.700314 & 0.868186 & -1.958468 & 0.0650 \\
\hline LNNOR & 2.074277 & 0.800754 & 2.590404 & 0.0179 \\
\hline LNDEBT & -1.324264 & 0.624562 & -2.120308 & 0.0474 \\
\hline C & -0.527802 & 1.950750 & -0.270564 & 0.7896 \\
\hline $\begin{array}{l}\text { EC }=\text { LNROA - (1.4211*LNCEX -1.7003*LNREX + 2.0743*LNNOR } \\
\text { *LNDEBT -0.5278 ) }\end{array}$
\end{tabular}

\section{9: Correction Short Run Error Test}

As revealed in the result in Table 9 below, error correction equation, CointEq(-1) has expected negative sign suggesting that it is statistically significant. It can also be seen that $99.6 \%$ of errors from the equilibrium can be corrected in the next period, and speed of adjustment is $99.6 \%$.

Table 9: ARDL Error Correction Regression

\begin{tabular}{|c|r|r|r|r|}
\hline Variable & Coefficient & Std. Error & t-Statistic & Prob. \\
\hline D(LNNOR) & 0.360692 & 0.451189 & 0.799425 & 0.4339 \\
\hline D(LNDEBT) & 4.610581 & 1.181314 & 3.902926 & 0.0010 \\
\hline CointEq(-1)* & -0.996374 & 0.152286 & -6.542762 & 0.0000 \\
\hline
\end{tabular}

\subsection{0: Causality Relationship}

From the table 10 below, ROA granger cause CEX (F-stat ROA $=5.95072$; Prob $_{\mathrm{ROA}}=0.0094$, significant at 5\%). ROA granger cause REX (F-stat ${ }_{\mathrm{ROA}}=2.64413$; Prob $_{\mathrm{ROA}}=0.0957$, significant at $\left.10 \%\right)$. Also ROA granger cause DEBT (F-stat ${ }_{\mathrm{ROA}}=4.42642$; Prob $_{\mathrm{ROA}}=0.0256$, significant at 5\%). That suggests a unidirectional causality between CEX, REX, DEBT and ROA. Only NOR has no identifiable causal relationship with ROA since their p-values are greater than the significant levels of $5 \%$ and $10 \%$.

Table 10: Pairwise Granger Causality Test

\begin{tabular}{|l|c|c|r|}
\hline Null Hypothesis: & Obs & F-Statistic & Prob. \\
\hline LNCEX does not Granger Cause LNROA & 25 & 0.68955 & 0.5133 \\
\hline LNROA does not Granger Cause LNCEX & 25 & 5.95072 & 0.0094 \\
\hline LNREX does not Granger Cause LNROA & & 2.53814 & 0.5921 \\
\hline LNROA does not Granger Cause LNREX & 25 & 0.52448 & 0.0957 \\
\hline LNNOR does not Granger Cause LNROA & 25 & 0.5998 \\
\hline LNROA does not Granger Cause LNNOR & 2.19238 & 0.5559 \\
\hline LNDEBT does not Granger Cause LNROA & 4.42642 & 0.1378 \\
\hline LNROA does not Granger Cause LNDEBT &
\end{tabular}

\section{5: Concluding Remarks and Recommendations}

This study went into much neglected area of research, relationship between fiscal policy instruments and performance of banks in Nigeria. Resounding empirical findings were made as follows; Bank performance is autoregressive. That suggests that performance of banks in the past cannot be predicting future bank performance. In fact, it is a good warning to banks not to leave on past glory and to always strive to retain the trust and confidence reposed on them by their various stakeholders. For instance prior to and after deregulation phase in the banking business in Nigeria (1986-1992), Firstbank, Union bank, United Bank of Africa and Afribank were referred to as the big four in Nigeria's coomercial bank categorization (Ejem, Ogbulu, Ogbonna, Oriko and Jombo, 2020). 
Today, it has been overtaken by FUGAZ ( Firstbank, UBA, GTBank, Access bank and Zenith bank). It conspicuously observed that Capital Expenditure, Non-Oil Revenue and Domestic Debt have positive and significant relationship with bank performance. This finding is plausible, corroborating Wagner's law of Increasing State Activity and Isek et'al (2020), while Recurrent Expenditure and Domestic Debt afterwards, negatively and significantly impact bank performance corroborating Debt Overhang Theory and Tchokote (2001) who recorded that the classical economists believe that debt issued by the public has no effect on the private sector savings. To them, a deficit financed by increasing the supply of securities, ceteris paribus reduces its price and raises real interest rates and this crowds out private investment. In sum, excessive deficit can lead to poor economic performance. It was also found that fiscal policy variables (Capital Expediture, Recurrent Expenditure, Non-Oil Revenue and Domestic Debt significantly impact bank performance both in the short run and long run confirming Njoku (2009) that though the ultimate aim of fiscal policy is the long run stabilization of the economy, yet it can only be achieved by moderating short run economic fluctuations.

Since fiscal policy variables are found to exert significant impact banks' performance in Nigeria, the researchers suggests to the regulatory and supervisory bodies emphasize more on fiscal policy to regulate banking sector in Nigeria. Proper mix of monetary and fiscal policies should be properly adhered to. In addition, Federal government of Nigeria as a matter of urgency reconsiders the operation of Treasury Single Account (TSA). It is the view of the researchers that the TSA be operated through deposit money banks (DMBs) by domesticating various Ministries, Departments and Agencies (MDAs) account with the DMBs. It should be noted that government is the highest spender in the economy. In sum fiscal policy should employed to curb the menace of non- performing loans in Nigeria since its efficacy is felt both short run and long run as discovered in this study

\section{Suggestion for Further Study and Limitation of Study}

As earlier said in previous study by the same authors, the subject should be extended to other financial institutions and across the frontier of Nigeria. This will help to validate possible inferences, theories and policy making. The study is limited to deposit money banks in Nigeria. The researchers had wished it was extended to both banking and non-banking financial institutions in Nigeria and other African countries but was hindered by unavailability of data to the researchers.

\section{References}

Aghevli, B.B. \& Khan, M.S. (1978). Government deficits and the inflationary process in developing conntries. IMF Staffpapers, 383- 416.

Ahmed, Q. M. (2010). Determinants of tax buoyancy: Empirical evidence from developing countries. European Journal of Social Sciences, 13(3), 408-414.

Amadi S.N, \& Essi I.D (2006). Government economic policy and Nigerian capital market behaviour; a causality analysis. Journal Development Alternatives Area Study, San Antonio USA.

Bhatia, H.L. (2002). Public finance (23 ${ }^{\text {rd }}$ edition). New Delhi: Vikas Publishing House Pvt Ltd.

Ejem, C.A., Ogbulu, O.M., Ogbonna, U.G., Oriko, B.O. \& Jombo, C.O. ( 2020). Foundations of banking, finance and insurance in Nigeria: An eclectic approach. Aba: Logicgate Media Ltd.

Ekpung, G.E., \& Udude, C.C. \&Uwalaka, H.I. (2015). The impact of monetary policy on the bankingsector in Nigeria. International Journal of Economics, Commercial and Management, 3(5), 1015-1031.

Ezirim, C.B. (2005). Finance Dynamics: Principles, techniques and application. Portharcourt: Markowitz Centre for Development.

Gregory, M. (2014). Principles of economics (7 ${ }^{\text {th }}$ edition). Stamford, CT: Southwestern Publishing Group.

Isek, F.C., Odumusor, C.J. \& Idor, R.M. (2020). Effect of fiscal policy on the performance of banks in the Nigerian economy. IOSR Journal of Economics and Financial (IOSR-JEF), 11(1), 55-60.

Jhingan, M.L. (2002). Macroeconomic theory (10 th edition). Delhi: Vrinda Publications (P) Ltd.

Lindgren, C, Garcia, G. \& Saal, M.I. (1996). Bank soundness and macroeconomic policy. Washington: International Monetary Fund, Publication Services.

Musgrave R.A. (1970). Fiscal systems, Review by: A.R. Prest The Economic Journal 80(318), 370-372

Njoku, P.N. (2009). Public finance: Sources, administration and management. Enugu: El'Demark Publisher.

Omodoro, C.O. \& Dandago, K.I. (2018). Fiscal policy and standard of living in Nigeria. Journal of Taxation and Economic Development, The official Journal of The Chartered Institute of Taxation of Nigeria, 17(1), 28-45.

Onoh, J.K. (2007). Dimension of Nigeria's monetary and fiscal policies-Domestic and external. Lagos:Astra Meridian Publishers.

Pattillo, C. (2001), External debt and growth. IMF, August 10. Punch Newspapers (2019). Huge growth in domestic growth published on the $10^{\text {th }}$ January, 2019.

Rose, P.S. \& Hudgins, S.C. (2010). Bank management and financial services ( $8^{\text {th }}$ edition). New York:McGraw Hill.

Sanni, A.(2012). Public expenditure and economic growth. African Journal economic policy 1(1). Nigeria, university of Ibadan Press. 
Taylor, T. (2017). Principles of macroeconomics: Economics and the economy (4 ${ }^{\text {th }}$ edition). Minneapolis: Textbook Media Press.

Tchokote, J. (2001). Macroeconomics of fiscal deficits in Cameroon. Being a Ph.D. Thesis Proposal presented to the Department of Economics. Ibadan: University of Ibadan.

Wagner, A. (1911). Staat in nationalokonomischer hinsicht, handworterbuch der staats wissenchaften,third edition book VII. Jena: lexis 743-745

Yusuf, M. A. (2017). Impact of fiscal policy on economic growth in Nigeria. Journal of Taxation and Economic Development, The official Journal of The Chartered Institute of Taxation of Nigeria, 16(2), 46-59. 